\title{
ANALISIS 5 C DALAM MEMPENGARUHI KEBIJAKAN KREDIT DI LPD DESA PAKRAMAN BANYUNING
}

\author{
Anton Sudiatmika Dwi Putra \\ Jurusan. Akuntansi Program Diploma III, \\ Universitas Pendidikan Ganesha, Singaraja \\ e-mail : Antonsudiatmika10@gmail.com
}

\begin{abstract}
Abstrak
Penelitian ini bertujuan untuk mengetahui bagaimana analisis $5 \mathrm{C}$ dalam mempengaruhi kebijakan kredit di LPD Desa Pakraman Banyuning. Subjek dari penelitian ini adalah LPD Desa Pakraman Banyuning, sedangkan objek penelitian ini adalah analisis $5 \mathrm{C}$ dalam mempengaruhi kebijakan kredit. Data yang telah dikumpulkan dalam penelitian ini kemudian di analisis menggunakan teknik analisis deskriptif kualitatif.

Hasil penelitian ini menunjukan bahwa prosedur-prosedur peminjaman kredit sudah melalui analisis 5C yang terdiri dari Character, Capital, Capacity, Condition of Economy, dan Collacteral. Dari analisis yang digunakan tersebut maka dapat diketahui bahwa proses peminjaman kredit di LPD Desa Pakraman Banyuning telah berjalan dengan baik dari tahun ke tahun. Hal ini dapat dilihat dari laporan keuangan tahunan pada LPD Desa Pakraman Banyuning dimana dalam laporan keuangan tersebut terlihat bahwa jumlah kredit yang bermasalah setiap tahunnya meningkat sedangkan presentasenya menurun, sehingga dari data tersebut dapat diketahui bahwa penyaluran kredit di Desa Pakraman Banyuning dapat dikatakan sehat.
\end{abstract}

Kata Kunci : Analisis 5C,LPD, kebijakan kredit

\begin{abstract}
This study aims to find out how 5C analysis in influencing credit policy in LPD Desa Pakraman Banyuning. The subject of this research is LPD Desa Pakraman Banyuning, while the object of this research is $5 \mathrm{C}$ analysis in influencing credit policy. The data that has been collected in this research is then analyzed using qualitative descriptive analysis technique.

The results of this study indicate that credit lending procedures have been through $5 \mathrm{C}$ analysis consisting of Character, Capital, Capacity, Condition of Economy, and Collacteral. From the analysis used it can be seen that the process of borrowing credit in LPD Desa Pakraman Banyuning has been running well from year to year. This can be seen from the annual financial report on LPD Desa Pakraman Banyuning which in the financial statements shows that the number of problem loans each year increases while the percentage decreases, so from the data it can be seen that the credit distribution in the village of Pakraman Banyuning can be said to be healthy.
\end{abstract}

Keywords: $5 C$ Analysis, LPD, credit policy 


\section{Pendahuluan}

Di Indonesia terdapat berbagai jenis lembaga keuangan baik skala besar maupun dalam skala kecil salah satunya yaitu Lembaga Perkreditan Desa (LPD). Tujuan Pendirian LPD menurut Peraturan Daerah Propinsi Bali No. 3 Tahun 2007 tentang Lembaga Perkeditan Desa adalah untuk mendukung pembangunan ekonomi perdesaan melalui peningkatan kebiasaan menabung masyarakat desa dan menyediakan kredit bagi usaha skala kecil, untuk menghapuskan bentuk - benttuk eksploitasi dalam hubungan kredit, untuk menciptakan kesempatan yang setara bagi kegiatan usaha pada tingkat desa, dan unttuk meningkatkan tingkat monetisasi didaerah pedesaan (Government of Bali, 1988, Government of Bali, 2002). Dalam menjalankan kegiatan operasionalnya, LPD sangat sarat akan risiko, oleh karena itu diperlukan analisis kredit yang tepat untuk menghindari terjadinya risiko-risiko tersebut. Dalam hal ini peneliti melakukan penelitian di Desa Pakraman Banyuning guna mengetahui pengaruh analisis kredit terhadap kebijakan kredit yang berlaku di Desa Pakraman Banyuning.

Berdasarkan latar belakang yang telah diuraikan, maka yang menjadi pokok permasalahan dalam penelitian ini adalah Bagaimana analisis $5 \mathrm{C}$ dalam mempengaruhi kebijakan kredit di LPD Desa Pakraman Banyuning? Adapun yang menjadi tujuan penelitian ini berkaitan dengan pokok permasalahan di atas adalah :untuk mengetahui bagaimana analisis 5C dalam mempengaruhi kebijakan kredit di LPD Desa Pakraman Banyuning. Hasil dari penelitian ini diharapkan dapat menambah referensi di perpustakaan. Hasil ini juga diharapkan bermanfaat bagi mahasiswa lain atau bagi peneliti lainnya yang ingin meneliti tentang Analss $5 \mathrm{C}$ Dalam Mempengaruh Kebjakan Kredit Di LPD Desa Pakraman Banyuning.

\section{Metode Penelitian.}

Berdasarkan permasalahan yang dirumuskan, maka penelitian ini dirancang untuk memperoleh informasi yang berkaitan dengan obyek penelitiannya mengenai analisis 5C dalam mempengaruhi kebijakan kredit di LPD Desa Pakraman Banyuning. Adapun rancangan penelitian yang digunakan adalah penelitian deskriptif dengan didahului mendatangi LPD Desa Pakraman Banyuning untuk menemukan permasalahan tentang analisis $5 \mathrm{C}$ dalam kebijakan pemberikan kredit dengan melakukan observasi, setelah itu dilakukan pengumpulan data. Jenis data yang digunakan adalah data kualitatif dari tahun 2010 sampai dengan 2015 yang bersumber dari dokumen-dokumen penting seperti: data amprah atau catatan- catatan lainnya yang mendukung dalam pengolahan data. Data-data tersebut diambil dan dikumpulkan dengan metode wawancara dan dokumentasi. Data yang dikumpulkan kemudian dianalisis dengan menggunakan teknik analisis deskriptif kualitatif.

Teknik analisis deskriptif kualitatif yang dimaksud adalah pengolahan data yang digunakan tidak berupa angka-angka yang dipergunakan dalam melengkapi dan mendukung pembahasan, seperti sejarah analisis pemberian kredit dan prosedur pemberian kredit. Sementara wawancara dilakukan kepada pihak-pihak tertentu dalam LPD yang tentunya berkaitan langsung dengan kredit. Hasil dari analisis data selanjutnya diperoleh kesimpulan bagaimana analisis 5C dalam mempengaruhi kebijakan pemberian kredit di LPD Desa Pakraman Banyuning. Penelitian ini dilakukan pada LPD Desa Pakraman Banyuning yang beralamat di Jalan Gempol 47 X, Desa Banyuning, Kecamatan Buleleng, Kabupaten Buleleng. Adapun subjek dari penelitian ini adalah LPD Desa Pakraman Banyuning. Sedangkan Objek peneltan ini adalah Analsis 5 C Dalam Mempengaruhi Kebijakan Kredit . Jenis dan Sumber Data

1) Berdasarkan Sifat Data

Adapun jenis data yang digunakan dalam penelitian ini adalah data kuantitatif dan data kualitatif. Data kuantitatif yaitu data berupa angka-angka dalam hal ini pinjaman yang diberikan kepada masyarakat dalam bentuk kredit. Sedangkan Data kulitatif adalah berupa keterangan-keterangan, uraian-uraian dan penjelasan mengenai kegiatan usaha dan 
penjelasan mengenai analisis $5 \mathrm{C}$ dalam mempengaruhi kebijakan kredit di LPD Desa Pakraman Banyuning.

2)

a) Sumber Data

Data primer

Data primer merupakan sumber data penelitian yang diperoleh secara langsung dari sumber asli (tidak melalui media perantara) seperti prosedur pemberian kredit.

b)

Data sekunder

Data sekunder merupakan data yang diperoleh secara tidak langsung yaitu melalui media perantara berupa catatan yang telah tersusun dalam arsip data LPD Desa Pakraman Banyuning seperti amprah atau permohonan kredit, sejarah perusahaan, dan struktur organisasi.

3) Metode Pengumpulan Data

Adapun metode pengumpulan data yang dilakukan untuk penelitian adalah:

a. Wawancara

Yaitu pengumpulan data dengan cara mengadakan tanya jawab secara langsung kepada pihak-pihak yang bersangkutan pada LPD Desa Pakraman Banyuning mengenai Analisis 5C dalam mempengaruhi kebijakan kredit

b. Dokumentasi

Yaitu pengumpulan data dengan cara mempelajari dan memahami data-data atau catatan-catatan yang berkaitan dengan analisis $5 \mathrm{C}$ dalam mempengaruhi kebijakan kredit di LPD Desa Pakraman Banyuning.

4) Teknik Analisis Data

Untuk memecahkan masalah yang dihadapi, maka teknik analisis data yang digunakan adalah teknik analisis deskriptif kualitatif. Analisis deskriptif kualitatif yaitu menguraikan atau menjabarkan dan menjelaskan segala informasi yang berkaitan dengan analisis 5C dalam mempengaruhi kebijakan kredit di LPD Desa Pakraman Banyuning.

\section{Hasil Dan Pembahasan}

Berdasarkan hasil penelitian diatas, adapun pengaruh analisis $5 \mathrm{C}$ terhadap kebijakan yang diambil oleh pihak LPD Desa Pakraman Banyuning diantaranya adalah sebagai berikut:

\section{Caracter (Watak Atau Kepribadian)}

Karakter dari calon debitur sangat mempengaruhi suatu keputusan pemberian kredit. Jika pemohon kredit sudah memiliki karakter kurang baik dan ingin mengajukan permohonan kredit, pihak LPD memberi kebijakan kepada pemohon dengan memberikan jumlah kredit sebatas jumlah kredit yang pernah diajukan oleh pemohon kredit. Hal ini sesuai dengan fungsi LPD yaitu sebagai wadah untuk meningkatkan perekonomian masyarakat sehingga pihak LPD akan mengutamakan masyarakat Desa Banyuning terlebih dahulu dalam penyaluran kreditnya.

\section{Capacity (Kemampuan)}

Capacity adalah kemampuan calon debitur dalam membayar kembali kredit yang telah diberikan. Namun jika pemohon tidak memiliki cukup kemampuan dalam membayar kredit sesuai dengan batas waktu yang telah ditentukan, maka pihak LPD akan memberikan kebijakan dengan kelonggaran jangka waktu pinjaman yang lebih lama dibandingkan dengan yang seharusnya, karena dengan diberikannya tambahan jangka waktu maka diharapkan pemohon kredit bisa membayar dengan lancar disetiap bulannya dari kredit yang akan digunakan dengan ditambahnya jangka waktu maka besarnya cicilan atau angsuran debitur tiap bulan semakin kecil atau rendah, secara matematika besarnya angsuran tiap bulanya ditentukan berdasarkan pokok pinjaman dibagi jangka waktu pinjaman, sehingga semakin lama jangka waktu akan semakin kecil angsuran atau cicilanya. 


\section{Capital (Modal)}

Capital atau modal mempengaruhi keputusan bagian kredit dalam memberikan jumlah kredit yang bisa dicairkan. Jika pemohon kredit tidak memenuhin analisis ini LPD masih bisa memberikan kredit dengan kebijakan pemohon kredit hanya bisa memperoleh kredit sebesar sisa jumlah penghasilan yang dimiliki setelah dikurangi dengan pengeluaranpengeluaran bersih selama satu bulan. Namun jika pemohon kredit menghendaki jumlah pinjaman yang lebih besar maka pemohon kredit wajib mengikutsertakan pihak ketiga dalam menandatangani perjanjian permohonan kredit dengan tujuan bila kemudian hari kredit mengalami masalah maka pihak ketiga ikut bertanggung jawab dalam pembayaran kredit.

\section{Condition of Economy (Kondisi Ekonomi)}

Kondisi ekonomi ini digunakan oleh pihak LPD dalam menilai jenis usaha yang akan dijalankan oleh pemohon kredit. Dalam menilai kondisi ekonomi yang tidak menentu pihak LPD menerapkan kebijakan-kebijakan yang harus juga dipenuhi oleh pemohon kredit seperti halnya adanya jaminan yang cukup memadai dalam permohonan kredit guna menguatkan posisi kredit yang akan dicairkan dikemudian hari bila terjadi sesuatu yang tidak diinginkan atas perubahan kondisi prekonomian yang mengganggu usaha pemohon kredit.

\section{Collateral (Jaminan atau Agunan)}

Pemohon kredit yang ingin mengajukan amprah namun tidak memiliki jaminan dan membutuhkan dana untuk keperluan yang sangat penting, LPD bisa membantu dengan memberikan kredit namun dengan kebijakan jumlah kredit yang diberikan hanya sejumlah 1 (satu) juta kebawah dengan jaminan pemohon kredit memiliki sebuah rumah. Namun jika pemohon ingin mengajukan kredit yang lebih besar kebijakan yang diberikan yaitu pemohon bisa menggunakan jaminan dari orang lain dengan syarat melampirkan surat kuasa dari pemberi jaminan dan diwajibkan mengikutsertakan pihak yang memberi pinjaman jaminan dalam penandatanganan perjanjian permohonan kredit.

\section{Simpulan dan Saran}

Hasil penelitian ini menunjukan bahwa prosedur-prosedur peminjaman kredit sudah melalui analisis 5C yang terdiri dari Character, Capital, Capacity, Condition of Economy, dan Collacteral. Dari analisis yang digunakan tersebut maka dapat diketahui bahwa proses peminjaman kredit di LPD Desa Pakraman Banyuning telah berjalan dengan baik dari tahun ke tahun. Hal ini dapat dilihat dari laporan keuangan tahunan pada LPD Desa Pakraman Banyuning dimana dalam laporan keuangan tersebut terlihat bahwa jumlah kredit yang bermasalah setiap tahunnya meningkat sedangkan presentasenya menurun, sehingga dari data tersebut dapat diketahui bahwa penyaluran kredit di Desa Pakraman Banyuning dapat dikatakan sehat. 
VOL.6, NO. 2, OKTOBER 2017

p-ISSN : 2337-537X

\section{Daftar Pustaka}

Suryanto Herli, Ali. 2013. Pengelolaan BPR dan Lembaga Keuangan Pembiayaan Mikro. Yogyarta:ANDI Yogyakarta.

Supriyono, Maryanto. 2011. Buku Pintar Perbankan. Yogyakarta: ANDI Yogyakarta.

Dwipa, Agung. 2015. Pengertian,Peran dan Fungsi Lembaga Perkreditan Desa (LPD). http://letsreadingme.blogspot.co.id/2015/05/pengertianperan-dan-fungsi-lembaga.html.

Diakses pada 30 Maret 2017.

Arnaya, N. 2014. 30 Tahun LPD Bali, Membangun Bali dimulai dari Desa Pakraman. Bali.

Kasmir.2015.Manajemen Perbankan. Jakarta: RajaGrafindo

Iskandar, Syamsu. 2013. Akuntansi Perbankan dalam rupiah dan valuta asing.IN MEDIA

Bank Indonesia Semarang, 2001. Bahan Pelatihan Satuan Pengawasan Intern BPR: Penilaian Tingkat Kesehatan Bank

Beberapa perundang- undangan perbankan peraturan Bank Indonesia yang ada di Website Bank Indonesia (www.bi.go.id)

Djumaha, Muhamad,2000, Hukum Perbankan di Indonesia, PT Citra Aditya Bakti, Bandung.

Jusuf, Jopie, 1992, Analisis Dasar Kredit Untuk Account Office, Intermedia, Jakarta

Jusuf, Jopie, 2010, Analisis Kredit Untuk Account Office, Gramedia Pustaka Utama, Jakarta.

Ikatan Akuntansi Indonesia, 1991, Prinsip Akuntansi Indonesia 1984, edisi revisi,Rineka Cipta, Jakarta

Kompas, 20 Juli 2012 halaman 20, hanya 19 Persen Rumah Tangga Berakses ke Bank (artikel)

Peraturan Bank Indonesia No.6/22/PB/2004 Tentang Bank Perkreditan Rakyat 9 Agustus 1004

Peraturan Bank Indonesia No. 8/26/PBI/2006 Tentang Bank Perkreditan Rakyat, Tanggal 8 November 2006.

Peraturan Bank Indonesia No./23/PBI/2001 tanggal 9 Agustus 2004 tentang penilaian kemampuan dan kepatutan (Fit and Propper Test) Bank Perkreditan Indonesia.

Peraturan Mentri Keuangan No 93/PMK.06/2010, Petunjuk Pelaksanaan Lelang. 